\title{
AMBULANT SALE OF FOOD IN THE STREET NEARBY EVENTS: THE ISSUE OF FOOD (IN)SECURITY FROM THE PERSPECTIVE OF THE CONSUMING PUBLIC
}

\author{
Diêgo Fernandes de Meloa; \\ Rafaela Caetano Pintob
}

\begin{abstract}
This article discusses issues related to the practice of street commerce near to events that occur in the Distrito Federal (DF), from the consumers' point of view. In order to do this, with the help of a survey, we sought to collect the information about the public's perceptions and consumption habits, to identify the elements that interfere in the option for consumption inside the event or with street vendors and how consumers evaluate the problem of food security in the provision of this service. The results demonstrate that $48.94 \%$ of consumers have a habit of consuming food sold by street vendors and that only $14.89 \%$ have knowledge about the rules of good practice in food handling and consider them when selecting consumption places of edibles.
\end{abstract}

\section{Palavras-chave}

Safety in events

Food Security

Street Food 


\section{INTRODUCTION}

In recent years the topic of safety in events has become an important aspect to be considered in the elaboration of projects, the activity realization is conditioned to the promotion of actions that reduce the possibilities of risks and guarantee the preservation of the integrity of its public. Among the issues related to safety in events, the offer of food in ideal conditions for consumption must be considered, since the impacts caused by the risks associated with the ingestion of contaminated edibles are harmful to the health of the participant and the image of the promoted event. In this context, the study is justified by the importance that the service offered has for event producers, as well as for the knowledge of students in the area. In addition, this subject deserves attention due to the low number of researches that link both themes: safety in events and food security, specifically walking trade.

However, the theme evokes a problem that is often beyond the control of an organizer: how is the street sale of street food and drink in the vicinity of the event? The present study aims to investigate the phenomenon of street vending of food, from the perspective of the consuming public, identifying the elements that lead them to choose this type of service, in addition to analyzing the way the same public evaluates the theme of safety/food insecurity inherent in the supply of street food.

To achieve the proposed objective, the research was developed with the application of a survey. In total, there were 94 respondents, all of whom lived in the Federal District (DF). The questionnaire contained questions about the socio-demographic profile of the participants, about their consumption habits and about the application of knowledge about the rules of good practices in food handling when choosing the place where to purchase and consume foodstuffs. .

\section{LITERATURE REVIEW}

\section{SAFETY IN EVENTS AND FOOD SECURITY}

The term security carries a broad social concept, almost always related to prevention and the absence of threats. This definition, however, is not able to cover some specificities of the term when applied to the practice of events. Andréa Nakane (2013), for example, in her work that - in the management stages of an event - the issue of security should not be viewed superficially since it implies not only the protection of the physical integrity of those involved but also an intangible content directly related to the subject's well-being and rejoicing.

This broader concept of security applied to Events may be related to food security as one of its important variables, since the Food and Beverage service is present in almost all types of events. In this case, there are many potential risks of contamination. Incidents of this nature can damage the participants' healthy, as well as the image of the event.

Thus, what does 'food security' mean? According to Luana de Assis (p. 13, 2018), the expression "is defined as the access of all people, at all times, to a nutritionally adequate, sufficient and safe diet (quality, quantity, and variety) to maintain an active and healthy life." It is obvious, in the concept presented, that the offer of "safe foods" implies the concern with the quality and the precedence of inputs, at the same time that it requires the care with asepsis in its handling, preparation, and storage, in order to do that no external elements compromise the final product that will be delivered to the consumer.

Assis (2018) points out three kinds of external agents that can offer a danger in food: biological, chemical, and physical. Microorganisms that promote food spoilage are called biological agents, they are "bacteria, molds, yeasts, viruses, parasites, prions and rickettsias" (Assis, p. 16, 2018). The same author emphasizes, however, that not all biological agents found in food are a real danger. For him "The presence of determined microorganisms can indicate flaws in the hygiene, handling or processing procedure, until the possibility of the spread of diseases (risks)" (Assis, p. 21, 2018).

Chemical agents are characterized as the residual elements from chemical products, such as pesticides, cleaning products, preservatives, toxins, heavy metals, among others, which can cause physical damage to people's health when found in overdosed conditions. For this researcher, "This group can cause harmful effects to consumer's healthy, acute or chronic" (Assis, p. $57,2018)$.

Finally, according to Assis (p. 67, 2018), physical agents are any foreign bodies that, not inherent to the composition of the preparation, are found in it at any stage of its production or service. If such physical agents do not cause harm to health, they must be treated as a contaminant; otherwise, they will be defined as a danger.

International and national organizations, being aware that most of the risks related to food insecurity are due to the incorrect handling of food, started to encourage instruments and subsidies that were able to assist in the production quality control, such as the management system Hazard Analysis and Critical Control 
Point, certified by Organização Internacional de Normalização (ISO); and the food library, edited by Agência Nacional de Vigilância Sanitária (ANVISA), that gathers all the norms, directly related to the theme, in force in Brazil

\section{CURRENT LEGISLATION IN BRAZIL ABOUT THE THEME AND THE MANUAL OF GOOD PRACTICES IN FOOD HANDLING}

The issue of sanitary control in the country, sometimes, presents as a complex theme due to the competences shared among the various state agencies, which stand out Agência Nacional de Vigilância Sanitária (ANVISA) and Ministério da Agricultura, Pecuária e Abastecimento (MAPA). Each of these is responsible for inspecting and controlling the production, distribution, and marketing of certain food products; however, in some cases, the same product may be subject to the regulations of both agencies. For example, MAPA is responsible for supervising products of exclusively animal origin, fresh vegetables, or beverages in general; however, when these products are processed and made available on the market, ANVISA's regulatory provisions also come into effect.

As the object of the present study is centered on the dimension of the street trade of foodstuffs, it was decided, in terms of the current legislation in Brazil that deals with the food theme; focus the research effort on the normative documents of that Agency, which are gathered on the platform "Biblioteca de Alimentos".

In this collection, called "Biblioteca de Alimentos", still due to the specificity of the study, it was chosen to emphasize the Resolution-RDC $n^{\circ} 216 / 2004$, whose content gives the origin to "Cartilha sobre Boas Práticas para serviços de alimentação". In it, the minimum provisions to be considered when planning food handling spaces are detailed, the structure must have dimensions and divisions that, at the same time, fit the activities developed there, facilitate cleaning and reduce the risks of cross-contamination; in addition to having clean drinking water, sufficient lighting and ventilation; as well as the practices to be adopted in the cleaning of the entire equipment, including caution with the use of sanitizers, pest control, waste handling among others; the basic care of asepsis and personal hygiene of food handlers and the mandatory capacity that affects them; the elements of quality control to be adopted from the stage of receiving the input to the display food for consumption; and, finally, the issue of documents, records, and tasks of those responsible for the sector.

Based on the booklet, establishments that offer food services are invited to develop their manual of good practices, describing, in this document, the work that is carried out in their place and the correct ways to practice it. It is possible to add the SOP (Standard Operational Procedure), with the details of each stage of production adopted in the establishment, so that the standardization of procedures can be observed by all handlers.

\section{THE PARADOX OF STREET FOODS}

According to Dutra (p. 9, 2012), street food is the food genre "offered to the public ready for immediate consumption, prepared and sold by vendors at stalls or semi-mobile stalls, which are installed in strategic points of the streets from a city". This definition, however, does not consider the social apparatus and the cultural sense related to the practice. In fact, the commercialization and consumption of street food, in addition to the availability of a quick and cheap meal in strategic points of the city, reflect the identity of the community where such activity is inserted and promote greater vitality to the urban space. On the other hand, they can raise concerns regarding the dimension of public health. These two realities related to street vending of food make the discussion on the subject broad and divide opinion among researchers.

Jacinto Júnior (2013), for example, defends the promotion of state initiatives that can encourage cultural production that is related to street food, especially because it has the faculty to reconnect people and build links between citizens and spaces urban equipment. The vision shared by Cardoso, Santos \& Silva (s / p, 2009), who explain the importance of this work activity from its social consequences, namely: "access to work, income and better quality of life" for the most vulnerable population. What makes them propose the need for strategic interventions to legitimize this informal job and to improve hygienicsanitary practices in relation to foodstuffs offered for consumption.

On the other hand, other authors prefer to focus on the question of the dangerousness of ingesting these preparations, since they are subject to a greater risk of contamination, mainly due to the low qualification of the handlers. Among them, it is possible to highlight Bezerra, Mancuso, and Heitz (2014), in whose article, they present data on disease outbreaks caused by foods (DOF), they list possible elements that hinder the action of health surveillance and list the flaws that make street food dangerous: food storage temperature and humidity, poor infrastructure at points of sale, lack of available drinking water, 
accessible bathroom, incorrect disposal of garbage, lack of an adequate food cooling system and frequent hygiene of hands, equipment and utensil hygiene.

Regardless of the point of view, obviously, everyone agrees with the statement that when it comes to the performance the activity there is an increasingly urgent need for improvements in the processes of handling, production, storage and service of the products made available for consumption so that the food supply is within the limits of quality and acceptable safety standards.

In order to approach this issue, in some States, there are own laws that regulate the street sale of food on public roads. Examples of this group are the state of São Paulo (Municipal Law n ${ }^{\circ 15,947 ~ / ~} 2013$ and Decree 55,085 / 2014) and the state of Rio de Janeiro (Organic Law ${ }^{\circ}{ }^{\circ} 6,272$ / 2017), whose legal provisions establish what are the prerequisites for the granting of the license, which products are allowed for sale and which hygienic-sanitary conditions must be met in the exercise of the profession of a street vendor of food. In the Federal District, there is still no similar normative instrument for street commerce. However, there is a law in the Federal Capital that provides for the sale of food in food trucks (Law No. 5,627 / 2016).

\section{PREVIOUS STUDIES ON THE SANITARY CONDI- TIONS OF COCONUT WATER AMBULANT TRADE AND FOOD TRADE AT OPEN MARKETS IN DF}

The absence of local legislation that regulates the street sale of food in the DF, associated with the lack of knowledge and/or disregard for the manipulators' compliance with good practices, contributes to the street food scene in the capital presenting in worrying hygienic-sanitary conditions. Developed researches by Beiró \& Silva (2009) and by Ribeiro \& Marangon (2011) are substantial evidence of this reality, which analyzed, respectively, the problems related to the sale of unsafe food in street markets and in coconut water carts in the Metropolitan Region of Brasília.

Beiró \& Silva (2009), based on RDC n 216/2014 - the regulatory instrument that approaches good practices for food services - and in RDC $n^{\circ} 218 / 2005$ - that approaches hygienic-sanitary procedures for handling food and drinks prepared with vegetables -, observed that, although in the context of open markets, all the surveyed establishments had certain adaptations to the legal provisions regarding the supply of water with quality and in satisfactory quantity. However, there was evident poor hygiene of the equipment and a small portion of this sample (less than 10\%) cultivated the habit of performing frequent hand hygiene (which, in about $40 \%$ of cases, was done only with water).
The same research showed that the risks of biological contamination of food, in addition to this issue of incorrect sanitary practices, were intensified by the use of adornments during the production stages, by the non-use or incorrect use of hair protectors, by the use of inappropriate clothing and, mainly, by the simultaneous manipulation of money. Which makes it possible to infer that the issue of food insecurity is more the result of human error regarding the observance of good practices than the availability of physical resources in the environment.

Ribeiro \& Marangon (2011), making an adapted use the research script prepared by Beiró \& Silva (2009), also found that the same pattern of inadequacies was repeated in the mobile coconut water trade, however, in this case, the aggravating factor of the absence of the water system that could favor the process of cleaning equipment, as well as manipulators and supplies. They also found that about half of the samples did not even have a storage structure for the coconuts, leaving them stored in plastic bags or in direct contact with the floor, so it was urgent to perform an asepsis and decontamination procedure before extracting its content and / or making it available for human consumption.

It is noteworthy to note that, In DF, the problem of food insecurity resulting from the incorrect practices of manipulating foodstuffs is not inherent in street vending or open markets. Fonseca \& Pereira (2013), when developing their cross-sectional study on the contamination of sandwiches in a sample of 167 snack bars registered in the Secretaria de Saúde do Distrito Federal, observed that $92 \%$ of the establishments had products with some level of contamination and in 33\% of these establishments the degrees of contamination by coliforms, staphylococci, Bacillus cereus, and Salmonella exceeded the acceptable limits defined by law, resulting in inappropriate products for consumption.

\section{METHODOLOGY}

This study seeks to evaluate the issue of street commerce of street food nearby events from the perspective of the consuming public and to identify the elements that guide the choice or not of this kind of food. It is denominated as exploratory research, since it aims to become familiar with a phenomenon and develop a new way of observing it (Cervo, Bervian \& Da Silva, p. $62,2007)$. In relation to methodological approach, it is quantitative, because "it uses structured procedures and formal instruments for data collection", emphasizing objectivity in the interpretation of the raw data collected (Gerhardt \& Silveira, p. 33, 2009). And, in re- 
lation to the procedure, it is a research with survey, since, through the use of a questionnaire, "it seeks information directly with an interest group about the data you want to obtain" (Gerhardt \& Silveira, p. 39, 2009).

In order to achieve the intended scope and better meet its characterizations, the research was systematized in two stages: in the first one, a study was developed in documentary sources about the themes related to the correct handling and conservation of food; hygiene of the person and sanitary conditions of the environment; and, finally, good practices and fundamental aspects of food security. For the purpose of this research, documentary sources are understood as the bibliographic collection available in a physical or digital medium, scientific articles publicly available in digital repositories of scientific production or institutional journals of Brazilian universities, legislation in force in the country and other official publications of Agência Nacional de Vigilância Sanitária.

On the second stage, which is based on food security prerequisites stipulated by Brazilian legislation and the Manual of good food handling practices, a survey was formulated, which contained questions about the frequency and preferences of street food consumption, as well as the consumer's relationship with the notions of food security and whether the occurrence of good practices or not interfered their power of choice in the selection of the place where would come to eat. The survey was applied, in person, on October, 5th, 2019, in a social event from Comunidade Vétero Católica Nossa Senhora do Encontro com Deus; and, virtually, by the use of the search tool called Fynzo Survey, its link was available, in the period between October 4th to 13th, through e-mail and WhatsApp social network, reaching the total number of 94 participants. Among participants, 60, 87\% were men, and 36, 96\% were women, the others preferred not to indicate gender. Most participants are between 25 and 35 years old (53.19\%) and between 35 and 44 (19.15\%); have incomplete higher education (48.94\%) or high school (24.04\%); and declare, as to marital status, single $(55.32 \%)$ or married (34.04\%). The other results obtained were treated analytically through quantitative data taking into account the Food Safety standards applied to food handling. The results are shown below.

\section{DISCUSSION AND RESULTS}

From the answers obtained by the research participants, it was found out that $97.87 \%$ of the respondents have a habit of buying food and drinks from street vendors, $12.77 \%$ making purchases every day and $25.53 \%$ do it two or three times a week. Among the most consumed items are: savory and baked and fried snacks (49.93\%), mineral water (46.8\%), canned drinks (19.14\%), sweets, and snacks (17.02\%) and barbecues (15.95\%). The numbers referring to the items consumed exceed the mark of $100 \%$ because the question allowed multiple choices.

Regarding the questioning of their consumption habits on occasions when they were participating in events, $48.94 \%$ of participants stated that they consume food and beverages sold by street vendors, while only $31.91 \%$ indicated they bought the same items in the official food court of the event. The price is the factor that most influences this consumption decision (68.08\%), followed by consumers' food preferences $(36.17 \%)$ and the hygiene conditions of the place (34.04\%).

Dealing specifically with food security, around $72.34 \%$ of participants stated that they are unaware of the rules of good practice applied to food handling or have only superficial knowledge on the subject. While $12.77 \%$ of the total stated that, although they are aware of the standards, they do not consider them when buying edibles. It can be elucidated by the indices presented below.

The results of the research on how the norms of good food handling practices interfere with the decision to purchase can be found in Table 1 :

Table 01 - Elements contained in Food Safety rules applied to food handling and their impact on the choice of place to buy food and drinks

\begin{tabular}{|c|c|c|c|}
\hline $\begin{array}{c}\text { Good Practice } \\
\text { Standard }\end{array}$ & $\begin{array}{c}\text { Percentage } \\
\text { of consid- } \\
\text { eration }\end{array}$ & $\begin{array}{c}\text { Percent- } \\
\text { age of } \\
\text { disregard }\end{array}$ & $\begin{array}{c}\text { Indiffer- } \\
\text { ence Index }\end{array}$ \\
\hline $\begin{array}{c}\text { Conditions for } \\
\text { storage and } \\
\text { conservation of } \\
\text { products, sup- } \\
\text { plies, and pack- } \\
\text { aging }\end{array}$ & 48,93 & 12,77 & 38,3 \\
\hline $\begin{array}{c}\text { Physical state of } \\
\text { the place }\end{array}$ & 65,96 & 8,51 & 25,53 \\
\hline $\begin{array}{c}\text { Proper packag- } \\
\text { ing and han- } \\
\text { dling of waste, } \\
\text { outside the area } \\
\text { of handling and } \\
\text { consumption }\end{array}$ & 91,49 & 2,13 & 6,38 \\
\hline
\end{tabular}




\begin{tabular}{|c|c|c|c|}
\hline $\begin{array}{c}\text { Good Practice } \\
\text { Standard }\end{array}$ & $\begin{array}{c}\text { Percentage } \\
\text { of consid- } \\
\text { eration }\end{array}$ & $\begin{array}{c}\text { Percent- } \\
\text { age of } \\
\text { disregard }\end{array}$ & $\begin{array}{c}\text { Indiffer- } \\
\text { ence Index }\end{array}$ \\
\hline $\begin{array}{c}\text { Hand hygiene } \\
\text { of the manipula- } \\
\text { tor and equip- } \\
\text { ment }\end{array}$ & 36,17 & 29,79 & 34,04 \\
\hline $\begin{array}{c}\text { Use of uniform, } \\
\text { gloves and hair } \\
\text { restraint }\end{array}$ & 65,95 & 4,26 & 29,79 \\
\hline $\begin{array}{c}\text { Hygienic- } \\
\text { sanitary condi- } \\
\text { tions of ice }\end{array}$ & 31,91 & 46,81 & 21,28 \\
\hline $\begin{array}{c}\text { No simultane- } \\
\text { ous handling of } \\
\text { money and food }\end{array}$ & 36,17 & 44,68 & 19,15 \\
\hline
\end{tabular}

Source: Research authors

Based on the collected data, it can be observed that the indifference index of participants was high in several aspects, such as conditions of storage and conservation of products, supplies, and packaging; hand hygiene of the manipulator and equipment; use of uniform, gloves and hair restraint, among others. In addition to this finding, the percentage of responses regarding the disregard for some protocols related to the safety of street food marketing is also high, such as the hygienic-sanitary conditions of ice and the simultaneous non-manipulation of money and food. On the other hand, it can be inferred that some questions are relevantly observed by consumers, such as the physical state of the place; the proper packaging and handling of waste, outside the area of handling and consumption; and the use of uniforms, gloves and hair restraint. In general, these indexes corroborate the studies by Bezerra, Mancuso \& Heitz (2014), when the authors bring to light the impasses in terms of sanitary inspection and the deficiencies that characterize the danger of street food sale. The data from this work also reinforces the research already studied by Ribeiro and Marangon (2011) and by Beiró \& Silva (2009) that map this scenario in DF.

Another interesting aspect shown in the table is the relationship, often non-purposeful, that exists between the food safety criteria most considered by participants and their visual/aesthetic representativeness. In fact, the item that participants declared most to appreciate relates to the presence/absence of garbage in the areas of food handling and consumption, followed by the physical state of the place and the use of uniforms; while hand hygiene and the simultaneous manipulation of money and food are considered a problem for only a small portion of individuals.

In addition, through research, it is noted that only $14.89 \%$ of participants declare to know the ResolutionRDC No. 216/2004 and consider its content when they need to choose the places to buy edibles. However, when participants were asked to reflect on real contexts, in which the standards could be applied, this percentage has a considerable increase in all situations illustrated. These issues, perhaps, allow inducing that some elements of the legislation (as the use of a clean uniform, a hair restraint, and gloves, which transmit the sensation of asepsis) are already culturally implicit in the research interest group and also unconsciously influence on their decisions.

\section{CONCLUSIONS}

At the end of the research, it is observed that the topic of food security needs to be further explored, looking for alternatives to improve the offer of safe food in the official food courts of the events, and also to raise public awareness about to the potential risks related to the purchase and ingestion of street food made by hawkers, if they do not comply with the guidelines contained in Resolution-RDC n 216/2004.

In this context, it is understood that safety in events, analyzed here through food security, has relevance to event producers as it does not stick to the technical aspects. It is also strategic because it deals with intangible aspects of the event, such as the integrity and well-being of the participants, in addition to the image of the event and the other agents involved, such as organizers, promoters, and sponsors.

Due to the relevance of the subject, it is expected that it will be a preliminary study, the results of which will stimulate the development of other research on the topic, in which information about the perception of other agents involved in the context could be collected, such as street vendors and event producers, so that the multiple perspectives support a more careful reading in relation to the investigated reality.

In addition, it is understood the relevance of regulatory frameworks that control street commerce in Distrito Federal, in order to guarantee qualified professionals to act in this type of work, as well as food security for consumers who purchase such products, in view of this practice being recurring and financially accessible to individuals. 


\section{REFERENCES}

Assis, L. (2018). Alimentos seguros: ferramentas para gestão e controle da produção e distribuição. 2 ed. São Paulo: Editora Senac.

Brasil. Agencia Nacional de Vigilância Sanitária - ANVISA. Biblioteca de Alimentos. Compêndio normativo. Available in: < http://portal.anvisa.gov.br /documents/33880/4967127/ Biblioteca+de+Alimentos_Portal.pdf/a458826b-f6e9-494ca45c-4ea1f8a9311d>. Accessed on: May 1st, 2019.

Brasil. Agencia Nacional de Vigilância Sanitária - ANVISA. (2004). Resolução - RDC № 216, de 15 de setembro de 2004. Estabelece procedimentos de boas práticas para serviço de alimentação, garantindo as condições higiênico-sanitárias do alimento preparado. Diário Oficial da União, Brasília, DF, September 17th, 2004.

Beiró, C. F. F.; Silva, M. Cl. Análise das condições de higiene na comercialização de alimentos em uma feira livre do Distrito Federal. Available in: <https:// www.publicacoesacademicas.uniceub.br/cienciasaude/ article/ view/883>. Accessed on: May 1st, 2019.

Bezerra, A. C. D.; Mancuso, A. M. C.; Heitz, S. J. J. Alimento de rua na agenda nacional de segurança alimentar e nutricional: um ensaio para a qualificação sanitária no Brasil. Available in: < $\quad$ https:// doi.org/10.1590/141381232014195.18762013>. Accessed on: May 5th, 2019.

Cardoso, R. C. V.; Santos, S. M. C.; Silva, E. O. Comida de rua e intervenção: estratégias e propostas para o mundo em desenvolvimento. Available in: <http://dx.doi.org/10.1590/ S1413-81232009000400027>. Accessed on: May 26th, 2019.

Cervo, A. L.; Bervian, P. A.; Da Silva, R. (2007). Metodologia Científica. 6 Ed. São Paulo: Pearson Prentice Hall.

Distrito Federal. (2016). Lei $n^{\circ}$ 5.627, de 15.03.16. Dispõe sobre a comercialização de alimentos em food truck no Distrito Federal e dá outras providências. Available in: < https:// www.tc.df.gov.br/sinj/ Norma/52994697c71a454d8fec9adf4ab7f581/ Lei 5627.html>. Accessed on: May 8th, 2019.
Dutra, R. C. A. Comida de rua: estilo alimentar. Temporalidade e sociabilidade nas ruas da cidade. Available in: < https:// www.anpocs.com/index.php/papers-36encontro/gt-2/gt07 -2/7917-comida-de-ruaestilo-alimentar-temporalidadeesociabilidade-nas-ruas-da-cidade/file>. Accessed on: May 27th, 2019.

Fonseca, J. G.; Pereira, M. G. (2013). Contaminação microbiana de sanduíches em lanchonetes: estudo transversal realizado em Brasília. Epidemiologia e Serviços de Saúde, [s.I.], v. 22, n. 3, p.509-516. Instituto Evandro Chagas. Available in: <http://scielo.iec.gov.br/pdf/ess/v22n3/v22n3a16.pdf>. Accessed on: May 12th, 2019.

Gerhardt, T. E.; Silveira, D. T. (organizadoras). (2009). Métodos de Pesquisa. 1a Ed. Porto Alegre: Editora da UFRGS.

Jacinto Júnior, W. Espaço público e comida de rua em São Paulo, uma questão cultural. Available in: < https:// paineira.usp.br/ celacc/sites/default/files/media/tcc/5841588-1-PB.pdf>. Accessed on: May 26th, 2019.

Nakane, A. (2013). Segurança em eventos: não dá para ficar sem!. São Paulo: Aleph.

Ribeiro, L. P., \& Marangon, A. F. (2011). Avaliação das condições de higiene dos carrinhos ambulantes de água de coco comercializada em Brasília-DF. Universitas: Ciências da Saúde, v. 9, n. 1, p. 1-12. Available in: < https:// www.publicacoesacademicas.uniceub.br/cienciasaude/ article/ view/1>. Accessed on: May 08th, 2019.

Rio de Janeiro. (2017). Lei $n^{\circ} 6.272$, de 01.11.17. Dispõe sobre o comércio ambulante do município e dá outras providências. Available in: <https://leismunicipais.com.br/a/rj/r/riode-janeiro/lei-ordinaria/2017/627/6272/leiordinaria-n6272-2017-altera-e-acrescenta-dispositivos-da-lei-n-18761992-quedispoe-sobre-o-comercio-ambulante-domunicipio-e-da-outras-providencias>. Acessed on: May 08th, 2019.

São Paulo (município). (2013). Lei $n^{\circ} 15.947$, de 26.12.13. Dispõe sobre as regras para comercialização de alimentos em vias e áreas públicas. Available in: < https:// leismunicipais.com.br/a/sp/s/sao-paulo/leiordinaria/2013/1594/15947/leiordinaria-n-15947-2013dispoe-sobre-as-regras-para-comercializacao-dealimentosem-vias-e-areas-publicas-comida-de-rua-e-daoutras-providencias>. Acessed on: May 08th, 2019. 
2014. Regulamenta a Lei $n^{\circ} 15.947$, de 26 de dezembro de 2013. Available in: <https://leismunicipais.com.br/a/sp/s/ sao-paulo/decreto/2014/5508/55085/decreto-n55085-

2014-regulamenta-a-lei-n-15947-de-26-de-dezembro-de-

2013-que-dispoesobre-as-regras-para-comercializacao-dealimentos-em-vias-e-areas-publicascomida-de-rua>. Accessed on: October 22nd, 2019. 